\title{
Rebound Effects of Exchange Rate and Central Bank Interventions in Selected ECOWAS \\ Countries
}

\author{
Mustapha A. Akinkunmi, \\ Brickfield Road Associates Limited, \\ 16, Akin Adesola Street Victoria Island, \\ Lagos, Nigeria \\ makinkunmi@fordham.edu \\ Department of Social Sciences \\ State University of New York, \\ New York, USA
}

\begin{abstract}
This study examines the exchange rate rebound effects of the Central Bank intervention in the selected ECOWAS economies. An empirical understanding of these effects is very important to trade adjustment as well as the macroeconomic stability in these countries. Using the panel data modelling framework, the study finds that the impact of the Central Bank intervention on exchange rate is insignificant and it does not lead to the exchange rate rebound. In addition, money supply as well as monetary policy rate implemented by the monetary authorities significantly influences the level of exchange rate in a positive direction.
\end{abstract}

Keywords: Rebound Effect; Intervention; monetary policy rate; panel data JEL: E58, F31, G28 


\section{Introduction}

Many developing economies adopted structural reforms to address challenges arising from the collapse of commodity market in the 1970s and the international oil market doom in the 1980s. Internal and external imbalances confronting these developing countries during the period, were triggered by the huge external debt problem and internal structural rigidities. Among structural reforms embarked in order to make the economy more competitive is devaluation and adoption of floating exchange rate regime.

The adoption of floating exchange rate regime has contributed to the volatility ${ }^{1}$ of exchange rate in most of these countries. The speed and rate of exchange rate fluctuations has attracted a lot of attention in literature to investigate its effect on investment and trade flows (Hooper \& Kohlagen, 1978) [29]. This issue receives a global focus as a result of the adoption of structural adjustment programmes (SAPs) by many developing countries like Nigeria, Ghana, Senegal and Sierra Leone etc., complemented with the exchange rate liberalization. Inconclusive results in the existing literature on the effect of exchange rate volatility on economy create a gap that this study intends to fill using the most recent data. Some studies like Adubi and Okunmadewa (1999)[5] revealed that exchange rate volatility poses an adverse influence on the level of agricultural export trade. They suggest that there is need for measures to reduce and stabilize the exchange rate.

However, achieving a fall in exchange rate is a great challenge confronting policy makers because of the following factors: Exchange rate volatility could hinder foreign investment flows as noted in Becketti and Sellon (1989) [9], based on the fact that the volatile exchange rate raises the investment risk through unpredictable rate of returns, and invariably leads to a reduction in investment level of foreign financial assets; the uncertain level of revenue from international trade arises from the exchange rate volatility as revealed in Lastrapes and

\footnotetext{
${ }^{1}$ Volatility captures the speed and rate of change rather than the direction of change.
} 
Koray(1990)[34], Adubi and Okunmadewa(1999)[5]; and the spillover effect of exchange rate volatility to the financial market as observed in Abel(1983)[1] and Bailey (1998)[7].

For instance, a rise in the exchange rate volatility leads to high risk of an asset, stock or bond, and contributes to the volatility of the asset price that could hinder the financial stability and make the monetary policy goals difficult to achieve. This buttresses why government devotes more attention on how to control exchange rate in the case of floating regime. Therefore, many countries, developed and developing, have adopted different measures to reduce the volatility level of exchange rate. The most common measures adopted include the intervention of the Central Bank in the foreign market with the aim of stabilizing the exchange rate. These interventions could be in form of sterilization and non-sterilization, depending on the monetary base of the Central Bank (Adubi, 2002)[4].

In the light of the above, this study intends to examine how effective Central Bank intervention in mitigating exchange rate volatility. Specifically, it investigates the exchange rate rebound effect of the monetary authority intervention in Nigeria, Ghana, Senegal and Sierra Leone. The fluctuations in exchange rate occur as a result of changes in the supply-demand equilibrium of currencies. The interventions of the central bank in the foreign exchange market without prior information might lead to the movement of the exchange rate. Invariably, the market participants will response to the intervention and the exchange rates will adjust based on the intervention-related information.

However, the effectiveness of Central Bank in stabilizing exchange rate has led to broadly two different school of thoughts. The first group is of the opinion that Central Bank intervention can reduce exchange rate volatility through addressing the issue of speculation against the currency while the second stream postulates that the Central Bank interventions could raise the volatility if the interventions add to market uncertainty or encourage speculation against the currency. 
Figure A.1 depicts exchange rate trends across ECOWAS countries in relation to the interventions ${ }^{2}$ and money supply implemented by the monetary authorities, from January 1990 to October 2016. For instance, the Nigerian government intervened in the foreign exchange market on June 2016 by supplying US dollars to the economy. Therefore, it is very relevant to verify the effect of the intervention with the harsh economic conditions confronting the region. In addition, it is very critical to examine how the exchange rate fluctuates after the intervention.

This study intends to provide an answer to the following research questions: How much exchange rates change as a result of the intervention and what levels of exchange rates would prevail if there is no intervention? This is important when investigating the intervention effects because such a rebound might likely reduce the relevance of the intervention as observed by Sarno and Taylor (2001) [49] and Takagi (2014) [52]. Scanty research has been done on exchange rate rebounds in ECOWAS region despite numerous ones on foreign exchange intervention.

The previous research works examined the extent of exchange rate fluctuations associated with the intervention and the virtual exchange rate that would have resulted in the absence of the intervention. This study adds to the existing literature by empirically analyzing how the exchange rate would be revised if a rebound existed. The study finds that the effect of foreign exchange intervention has no rebound on the exchange rate in the selected countries.

\subsection{Significance of the Study}

The exchange rate is widely acceptable as a strong and important economic indicator needed to evaluate the performance of the entire economy. It also captures the strength or the weakness of an economy. Prior to Structural Adjustment Programmes (SAPs), many ECOWAS countries like Nigeria utilized a fixed exchange rate regime which does not allow fluctuations in exchange rate. The failure of the fixed rate regime to engineer the expected dividend led to the adoption of flexible regime in 1986 with the aim of achieving effective

\footnotetext{
${ }^{2}$ The change in the foreign reserve is used as a proxy for the intervention as suggested in the literature
} 
exchange rate management. In addition, the main aim of exchange rate policy in the ECOWAS region is to attain a realistic and stable exchange rate in line with internal and external balances, complemented with the core role of being macroeconomic policy.

Despite the implementation of different measures to achieve a stable exchange rate, the exchange rate stability in the African sub-region still remains elusive as a result of difficulty in moving resources to the productive sectors, and an increase in monitoring problems and costs etc.

The heavily import-dependent nature of the ECOWAS economy contributes a great concern on the issue of exchange rate instability. For instance, at the inception of Nigeria's flexible exchange rate regime in 1986, one \$ was equivalent to $\$ 4$, and rose to $\$ 134$ by March 2001 . The huge magnitude of exchange rate fluctuation was recorded within 15 years. This led to negative effects on production, consumption, inflation, standards of living and employment to the extent that the country's gross domestic investment(GDI) as a ratio of Gross Domestic product(GDP) declined from 28.3 percent in 1977 to 15.3 percent in 1997 . However, Indonesia that shares the same economic features with Nigeria experienced an increase of about 35.8 percent in its GDI as a ratio of GDP from 23.4 percent in 1977 to 31.8 percent.

Therefore, identifying the effectiveness of different central bank measures such as deregulated exchange rate policies, guided deregulation, dual exchange rate system, the introduction of different exchange rate markets, intervention and monitoring of participating agents in foreign exchange transactions is cursorily examined.

Out of these measures, the direct intervention of the monetary authorities is the only one that influences the operations of the market system directly, and is carried out by increasing the supply of foreign exchange to the exchange rate market with the creating supply-demand equilibrium in the market. Therefore, it is very important to quantitatively investigate the link between this intervention mechanism and the exchange rate volatility. If it is ineffective, other indirect measures need to be implemented to maintain a stable exchange rate market.

The inability to cope with the macroeconomic instability for long in developing regions like ECOWAS without collapsing requires a rigorous and most recent research that provides a comprehensive policy- oriented 
framework to ensure exchange rate stability in the region given the exchange rate critical role in macroeconomic management.

The rest of this paper is segmented into four sections. Section Two reviews recent literature in the context of the monetary authority interventions and exchange rate, while conceptual framework and methodology is provided in Section Three. Section Four presents and analyses empirical data, as well as result discussion. Concluding remark is presented in Section Five.

\section{Literature Reviews}

\subsection{Theoretical Review}

\subsubsection{Exchange rate stability and Central Bank Interventions}

The exchange rate without rapid changes reflects the exchange rate stability. This also occurs when it fluctuates within a specified threshold. The stability of exchange rate relies on the following: supply of and demand for foreign exchange; the type of exchange rate system in practice; the adequacy and appropriateness of complementary monetary and fiscal policies. The exchange rate stability implies that the movements in rates from one period to another are small, and the divergence between the various is also minimal (Olisadebe, 1995) [45].

The central bank authorities intervene in the foreign exchange market with the aim of controlling the exchange rate and ensuring more stability. The one source of intervention is the exchange stabilization fund set up in the 1930s. The fund is implemented by encouraging the control authority to act as an independent trader in the foreign exchange market. The control authority acts as a buyer or seller in the exchange rate market in order to influence the supply and demand schedule and thus exchange rate.

Many developing economies intervene in the exchange rate market through their own currencies. This method is termed as "the fear of floating" as suggested in Calvo and Reinhart (2000)[12]. The fear of floating is also 
carried out by developed economies as well. For the emerging economies, the fear of floating is applied when their currencies below the target level, and is better diagnosed as a "dread of depreciation".

The CBN reduces the value of foreign currency against the local currency by buying naira assets with dollars. This leads to a rise in dollar reserves in the foreign exchange market and invariably to an increase in foreign currency supply if all other things remain constant. This action influences the exchange rate volatility based on how its impacts on the causes of the volatility.

The monetary authority can put a threshold publicly or privately and encourage the market interactions of demand and supply to determine the price. Its intervention occurs when the movement of the price deviates from the threshold either positive or negative.

In addition, the intervention of the monetary authority can be sterilized (unchanged monetary base of the bank) or unsterilized (changed monetary base). For instance, the buying or selling of foreign exchange by the monetary authority increases or decreases the monetary base by the amount of purchases or sales of domestic securities. This type of the transactions affects exchange rate in a similar manner as domestic open market purchases or sales of domestic securities does. Neely (2000) [41] pointed out that monetary authority could sterilize the foreign exchange operations through purchasing and selling domestic bonds. The sterilized intervention is recorded when there is no direct influence on the volatility of the actual market fundamentals such as money supply, interest rates or income.

Theoretically, it might likely influence the exchange rate through two channels based on Wickham (2002) [54]. First is the portfolio balance channel, where the intervention can affect the relative volume of domestic and foreign bonds in the hands of the public. Second is the "signaling channel" which relies on the assumption that official intervention provides a signal about future monetary policy or the long term equilibrium value of exchange rate. For instance, the $\mathrm{CBN}$ intervened in the foreign exchange market in two occasions during the 1986. The first intervention is when the initial foreign exchange supply was increased from $\$ 75$ million to $\$ 86$ million in order to address the naira depreciation. The second one is done to prevent the naira appreciation. 


\subsubsection{Effects of Central Bank. Interventions}

There is absence of well-defined rules guiding the intervention of monetary authorities in the foreign exchange market in most developing countries unlike the developed economies that follow IMF principles in the process of interventions. Impacts and direction of Central Bank interventions in the exchange rate market relies on how the interventions influence the causes of volatility. The influence of the intervention is established mainly in the market expectations and speculative behaviour.

The two channels in which the interventions can reduce the volatility of exchange through removing the uncertainty about future monetary policy, and second, by reducing the possibility of speculative bandwagon effect, and hence reduce exchange rate volatility. It is widely believed that the CBN intervention would occur when speculative forces become dominant. The belief makes speculators reluctant to take any quick action.

The exchange rate volatility is likely to increase when the intervention raises the operators' uncertainties about the monetary authority policies in relation of the existence, magnitude, and period of intervention. This might lead to unpredictable and more volatile exchange rate in the presence of intervention. This implies that uncertainty about the monetary authority intervention is potentially an important source of exchange rate volatility. This could result into greater exchange rate volatility. Therefore, uncertainty over the intervention policy could add to exchange rate volatility.

The increased probability of speculative bandwagon in the presence of the intervention can increase the exchange rate volatility. For instance, the volatility would increase if the market operators believe that the monetary authority cannot prevent the speculative forces for controlling the movement of exchange rate. Therefore, the uncertainty about the intervention can trigger speculation and cause price changes and exchange rate volatility to be greater than in no such intervention.

Similarly, in some situations, the intervention might not influence the exchange rate volatility because the foreign exchange market is large enough to make the intervention amount an insignificant share of the total volume of trade. For example, $\$ 600$ billion of total trade volume against $\$ 200$ million of the monetary authority intervention in the foreign exchange rate market. 
The above-theoretical explanations are unclear about the impact of the intervention on exchange rate fluctuations. Also, the effects vary over time due to changes in the credibility of intervention policy. Therefore, this calls for empirical-based evidences to examine the effects of intervention on exchange rate and thus sheds more light on the ability of the intervention to achieve stable exchange rates.

\subsubsection{Foreign Exchange Policy Management in Selected ECOWAS Countries}

\subsubsection{Nigeria}

Before the introduction of 1986 SAPs: the exchange rate policy became a policy issue in Nigeria in the late 1980s because the pegger nature of the developing countries like Nigeria. The Naira was initially pegged to the British pound sterling and later to the US dollar based on the Bretton Wood System of exchange rate management.

The country's exchange rate policy can be broadly segmented into periods or stages. The first period (19601967) was the era of a one-to-one relationship between the Nigerian pound and the British Pound Sterling. This continued till 1967 when the British pound was devalued. The Nigeria's monetary authority did not devalue its currency because of the ongoing civil war. It is during this era that the country joined the International Monetary Fund (IMF) in 1961.

The country replaced the pound with its own currency (Naira) in January 1973 and its par value was set at half of that of the pound while one naira was equivalent to $\$ 1.52$. The anchor currencies, dollar and sterling experienced weak value during most of 1973. This led to indicate the disadvantage of fixed exchange rate regime because the regime is not sustainable if the country intended to respond independently to economic changes. There was the adoption of a policy of progressive appreciation of naira against the dollar and the sterling in April 1974. This coincided with the first oil boom. The policy was aimed at ensuring that the naira exchange rate indicates the position of balance of payments in the country attributed to the oil boom (Komolafe, 1996)[32]. 
The misfortune in the oil sector (falling reserves) halted the policy in the late 1976 and reversed the policy to capture the changed fortunes in its economy. The need to achieve a relatively stable exchange rate led to the use of currency basket.

Between 1978 and 1985, the country adopted a policy to base the exchange rate on a basket of the currencies of Nigeria's major trading partners. The basket of currency in exchange rate was determined to portray the developments in the international foreign exchange market. Reducing the fluctuation of import prices was considered as the merit of the system (CBN, 1998)[13]. However, the fall in the global crude oil prices and the crisis of commodity markets in the 1980s led to the collapse of the policy.

The factors such as dwindling oil prices as well as the prices of major export goods, and rises in real international interest rates contributed to the economic downturns (Faruque, 1994)[24]. In addition, there was a significant decline in the oil share of government revenue from 93.4 percent in 1973 to 70.3 percent in 1981, 69 percent in 1983 and 72.6 percent in 1985. However, it is difficult for government to curtail its expenditures. This translated to a rise in budget deficits, imports and growing balance of Payment deficits. The government attempted to address these economic problems by introducing the economic stabilization measure in April 1982 with the purpose of adjusting the economic structure and diversifying the sources of foreign exchange earnings. In addition, there was a restriction and prohibitions on a wide range of industrial and consumer imported goods. The life of the measure extended to 1984 when the exchange control measures were introduced. The new measure included sectoral allocation of foreign exchange, tough import licensing that reduced the importation of machinery and transport equipment.

An additional policy was included to depreciate the naira value in 1985 and it extended till 1986. The economic situation remained the same in the in spite of increasing trade and payment control. In the middle of 1986, Structural Adjustment Programme(SAPs) was introduced due to the seemingly unabating internal and external imbalance problems. Nigeria migrated from the hitherto fixed exchange rate regime to flexible exchange rate in September 1986 through the introduction of the second-tier foreign exchange market. 
The flexible exchange rate system allows the value of naira to be determined by the strength of demand and supply of foreign exchange. However, the monetary authority still maintained the discretionary rule in intervening in the exchange rate market to ensure stability and achieve policy objectives. The monetary controls failed to attain its policy goals because of wide fluctuations in the exchange rate over the years.

This gave birth to the introduction of the second-tier foreign exchange market (SFEM) decree in September 1986. The SFEM decree promulgated a flexible or floating exchange rate regime with the focus of eliminating existing distortions and imbalance in the external sector of the economy as well as ease its persistent balance of payment problems through achieving a desirable and realistic exchange rate for the naira. With the inclusion of auction system, the IMF reclassified the country as an independent floater.

However, the system confronted a variety of problems such as the destabilizing speculative activities of dealers and bidders in the market, accumulated demand pressure against inadequate supply of foreign exchange etc. (Komolafe, 1996) [32].

From 1986 onwards, different several measures such as the Dual Exchange Rate System (1986-1987; 19951999), unified exchange rate system(1987-1988), Fully Deregulated Exchange Rate System (1992-1993), The Fixed Exchange Rate System (1994); Fully Deregulated Exchange Rate System(1999); have been adopted in the foreign exchange market in order to reduce exchange rate volatility and ensure stability in the market. The stable exchange rate remained a mirage despite different exchange rate regimes in the country. The interventions had no significant effect on the forces of supply and demand in the market. The intervention in supply was not sufficient to satisfy the demand upsurge.

The effectiveness of the monetary authority policies in the future relies on how well the policies designed to address the major causes of the problems of the currency such as excess liquidity and huge extra-budgetary expenditure on unproductive ventures; heavy debt service burden; speculative demand driven by social and political uncertainties; and unbridled importation. 


\subsubsection{Ghana}

The introduction of stabilization programme in 1983 was followed by the adoption of SAP with the aim of restoring fiscal and monetary disciplines, and adjusting prices through putting an end to all controls. The SAP led to the launch of the Financial Sector adjustment programme (FINSAP) in 1987 to proffer solutions to the deterioration problems in the financial sector (Maehle, Teferra, \& Khachatryan, 2013)[36].

The Ghanaian currency was effectively devaluated from 2.75 cedis per US\$ to average rate of 24.7 cedis per US dollar in April 1983. This devaluation arose from the adoption of a transitional multiple exchange rate system. In October 1983, the system was put to an end and the exchange rate was 30cedis per US dollar uniformly. The country implemented a constant real exchange rate rule that is periodically adjusted in line the inflation differential between Ghana and its main trading partners between 1983 and 1984. In order to attain a real effective exchange rate depreciation, there was 18 percent devaluation in October 1983, 15 percent in MarchApril 1984, 9 percent in August-September 1984, 21 percent in December 1984, and 45 percent between end 1984 and January/February 1986(led to 90cedis per US dollar).

In June 1985, authorized foreign exchange dealers were allowed to open foreign deposit accounts. The official transaction window of fixed rate of 90 cedis per US dollar and the one retail auction based window for all other transactions were merged in February 1987. All foreign exchange rates were determined at the auction platform.

In February 1988, the huge absorption of the parallel foreign exchange market led to the creation of two spot foreign exchange markets. The two spot-market rates were unified as the licensed bureaus can participate in the market. In March 1992, interbank foreign exchange market replaced the weekly wholesale foreign exchange auction (Maehle et. al., 2013)[36].

\subsubsection{Senegal}

Many economic adjustment programs implemented in Senegal recorded insignificant progress. This led to the use of competitive depreciation policy in January 11, 1994 in order to boost the economic competitiveness. 
Prior to the introduction of the Euro in 1999, the CFA franc was devalued by 5o percent against the French franc (Kireyev \& Mansoor, 2015)[31].

\subsubsection{Sierra Leone}

Unlike other less developed economies, the country maintained the use of the fixed exchange rate regime after the demise of the Bretton Woods System in the early 1970s. Its reluctance was largely attributed to the panic that such measure might reduce the value of the Leone and raise the inflation through the exchange rate passthrough transmission. However, owing to the persistent balance of payment problems, different exchange rate adjustments were made in the 1980 s and finally led to the adoption of the managed floating exchange rate regime in 1990(Korzu \& Braima, 2009) [33].

The first currency devaluation in the country in November 1967 after the pound sterling was devalued by 14.3 percent. This was done with the motive of controlling capital outflows arising from the devaluation of the pound sterling. The Leone was fixed at one-to one ration with the British pound in 1967 till 1978 when it was exchanged as Le 2 per one British pound. A dual exchange rate system was adopted in December 1982 under the Modified Exchange Rate Arrangement (MERA) because of the falling economic performance of the early 1980s. This entail both an official exchange rate and a commercial market rate. The official exchange rate of Le 1.52 per US\$ was prevailed while no definite rate occurred in the commercial market. This system allowed the diversion of export earnings from the official market to the official market to the parallel market.

Despite the adoption of the unified exchange rate regime in July 1986, its fiscal deficits still escalated. Three devaluations were done between August 1987 and January 1990 as a result of inconsistent monetary expansion with high inflation and real exchange rate appreciation. In April 1990, most current account transactions were liberalized with the managed floating exchange rate system. The widening premium between the official and parallel market rate in the fixed exchange rate regime was the driving factor for adopting the managed floating exchange rate regime (Korzu \& Braima, 2009)[33]. 


\subsection{Empirical Review}

Hoshikawa (2017)[28] examined rebound effects of exchange rate after the monetary authority interventions using daily data from April 1991 to March 2014 in Japan. The results from estimation techniques such as OLS, GARCH and EGARCH revealed that the presence of rebounds in the exchange rate after the intervention, and the effectiveness occurs in the next day of the intervention.

Miyajima and Montoro (2013)[38] empirically analyzed the influence of foreign exchange interventions on exchange rate expectations in selected emerging economies (Brazil, Peru, Korea and Malaysia). The estimation results of the fixed effect panel model using monthly data spanning from June 2004 to August 2012, indicated that sterilized central bank foreign intervention poses little systematic effect on the near term nominal exchange rate expectations in line with the intended target of the central banks.

However, Mongkol (2011)[39] utilized a descriptive survey to examine the effectiveness of intervention in Thailand. He concluded that the Central Bank's intervention is not effective, and low because the monetary authority believes that exchange rate is determined through market mechanism.

Similarly, Saccke(2002)[47] conducted the technical analysis of the effectiveness of the central bank intervention by random walk and GARCH on daily data from January 2, 1979 to July 25, 1994. He confirmed that moving average trading rules are highly profitable on days when central banks intervene, and also the trading rules tend to bet against central banks.

Mbarek, Rachidi and Mensi(2011)[37] analyzed the effect of Central Bank intervention on the exchange rate in Tunisia using simultaneous system model and VAR model on daily data from April 1999 to June 2006. The results showed that the interventions exhibit a significant influence on the return of the rate, complemented with a high tendency of persistent exchange rate fluctuations.

Chen, Funke and Glanemann(2011)[15] employed a signaling channel to examine the link between monetary authority intervention and exchange rate in Japan for the sample period, January 1999-31 March 2011. 
Adam, Kosinski and Zielinski (2013)[2] examined the extent at which the central bank intervention affects exchange rates in Poland using daily data spanning from 6 June 2011 to 22 September 2011. The OLS estimation results indicate that the central bank policy was effective, and the implied volatility of the currency reduces as the intervention commences.

On the other hand, Benita and Lauterbach (2007)[11] applied both panel data and specific country analysis to examine the relationship between policy factors and exchange rate volatility among 44 countries using GARCH and regression models. They found a positive correlation between exchange rate volatility, real interest rates and the intensity of central bank intervention, whereas real interest rates and central bank intervention established a negative correlation with exchange rate volatility for the case of Israel.

In the same vein, Adler and Mano (2005)[3] utilized the panel technique to investigate the effects of foreign exchange rate intervention among 13 advanced economies and 39 emerging countries with the use of monthly data from January 1996 to October 2013. Their outcomes revealed that a 1\% purchase of foreign currency leads to a decline of nominal exchange rate by ranging of $1.7 \%$ and $2 \%$, and thus a fall in real exchange rate by ranging of $1.4 \%$ to $1.7 \%$ respectively. In addition, the symmetric effect is established.

Chipili (2014)[16] empirically analyzed the effect of exchange rate volatility on macroeconomic management in Zambia using monthly data from 2007 to 2013 . He estimated both the GARCH model and SVAR model in which he found that exchange rate volatility reduces trade exports and imports, and thus influence on output and inflation. The exchange rate volatility also adversely affects the short term capital flows. This suggests the relevance of exchange rate in trade and monetary policies, as well as the transmission of exchange rate impulses to the rest of the economy.

Galati, Melick and Micu(2002)[26] conducted an empirical study on the foreign exchange market intervention and expectations in Japan and United States by employing daily data for the sample period September 1993 to April 2000. The results of hermite polynomial approximation show that intervention does not significantly influence the mean of yen/dollar appreciation, and the intervention is not accompanied with a rise in the tails 
of the distribution of exchange rate expectations. Additionally, they identified that intervention was not in line with underlying fiscal and monetary policy, which had little effect on market outcomes and expectations.

Disyatat and Galati (2005)[19] analyzed the effectiveness of foreign exchange rate intervention in Czech with the daily data from September 2001 to October 2002. The findings from probit and regression model with instrumental variables indicate the insignificant effect from interventions to the spot exchange rate, the risk reversal and short time exchange rate volatility.

\subsubsection{Empirical Literature in Nigeria}

A lot of research has been done on investigating the behaviour of the exchange rates as well as the influence of parallel and/or informal market on the exchange rate stability in Nigeria (see Ogiogio 1996[44]; Ahmed and Zarma 1998[6]; and CBN/NISER 1998[13]). However, scanty or little research has been carried out to examine the rebound effect of central bank intervention and exchange rate in West African countries.

For instance, Olisadebe(1995)[45] investigate the role of central bank of Nigeria in exchange rate management. He concluded that effectiveness of CBN intervention in the foreign exchange market is a function of its level of autonomy and the amount of foreign exchange at its disposal. Obadan(1993)[43] identified the factors that led to exchange rate instability to include excess demand for foreign exchange amidst insufficient funding of the foreign exchange market, poor performance of autonomous sources of foreign exchange inflow, instability of the crude oil market, speculative activities and sharp practices of authorized dealers, and expansionary monetary and fiscal policies that increase demand pressures in the market. In addition, Obadan(1993)[43] pointed out that the rising demand figures arising from the frequency of bidding and the character of the demand itself.

However, Ogiogio(1996)[44] examined the macroeconomic policy features of all the six phases of the auction system between 1986 and 1991 in relation to their effects on exchange rate. His results revealed that the level of depreciation of the naira-dollar exchange rate was significantly affected by the type of auction system adopted. Also, the frequency of bidding influenced the rate of depreciation. 
Adubi and Okumadewa(1999)[5] investigated the link between exchange rate volatility and the volume of agricultural exports. They established that existence of a negative effect from exchange rate volatility to the agricultural exports, but a positive effect from price volatility. Their conclusion is that the more volatile the exchange rate changes, the lower the income earnings of farmers, which invariably leads to a fall in output production and a drop in export trade.

\subsection{Methodological Review}

Besides the policy question about exchange rate being a target of economic policy, why and how intervention influences the exchange rate remains inconclusive (Sarno \& Taylor, 2001)[49]. The response to this depends on the method of analysis particularly when intervention is typically sterilized (Wickham, 2002)[54].

For instance, the portfolio balance approach points out that Central Bank intervention affects the relative supply of outstanding domestic and foreign bonds, whereas the signaling channel approach proposed by Mussa(1981)[40], considers the intervention as a means of revealing information about the future path of monetary policy, entailing expectation revisions and revaluation of exchange rates.

The noise trading hypothesis of Hung (1997)[30] is based on the assumption that there are at least participants in the foreign exchange market and the influence of well designed and implemented interventions on exchange rate can be magnified by changing their trading positions. Others such as Chaudury and Wei (1994)[14] agree with the noise trader hypothesis of intervention. This implies that a given trend in exchange rate is associated with both participants and Central Bank intervention.

Clarida et al. (2001)[17] considered a Markov regime switching model as a natural tool to examine the pattern of exchange rate behaviour. In addition, Le Baron(1999)[35] buttressed this argument by postulating that the profitability of a simple trading rule depended on moving averages was magnified when there is intervention in the foreign exchange market.

Neely and Weller (2001)[42] used a dummy variable to distinguish between intervention and no-intervention periods. Their outcomes led to the conclusion that interventions statistically significantly influence the exchange 
rate expectation. Reitz (2002)[46] concluded that the dummy variable of intervention accounts for exchange rate volatility.

Dutta and Leon(2002)[21] investigated the dynamic influence of intervention on exchange rate for 27 advanced and emerging economies. They revealed that intervention is universally common among the concerned countries, and used when nominal or real exchange rate depreciates. In addition, the degree of persistence in real exchange rates is reduced as a result of intervention; and there is tendency for contradictory situation during the defence of an overvalued currency.

Numerous studies such as Edison (1993)[22], Sarno and Taylor (2000) [48], and Neely (2000)[41], examined the drivers and efficacy of intervention. Spolander(1999)[50] employed a model-consistent technique to measure exchange market pressure and intervention policy in a floating exchange rate and sterilized intervention system in the context of an small open-economy. His results found that the measures of exchange market pressures and intervention policy are more realistic and thus easier to interpret when monetary policy reaction function is considered.

Furthermore, Galati and Melick (2002)[26] examined the influence of interventions on exchange rate market using data on market expectations. They concluded that the effect of intervention substantially differs across episodes of exchange rate movements. In addition, the result of an econometric approach indicates that intervention on its own, had no statistically significant and systematic influence on the expected future exchange rates.

The behaviour of daily spot exchange rates was investigated by Wichkam(2002)[54] for the developed economies with the floating exchange rate system and for the developing countries whose regime was flexible. He found that the effect of intervention varies, based on the regime during intervention and the approach of examining intervention. Therefore, he suggested several methods such as mean variance approach, and econometric technique etc.

Reitz (2002)[46] applied a generalization of the noise trader transmission mechanism to analyze the effect of Central Bank intervention on exchange rates using the Markov regime-switching approach. 


\section{Conceptual Framework and Methodology}

\subsection{Conceptual Framework}

Broadly, exchange rate volatility refers to unexpected and unpredictable fluctuations in exchange rate. It could be in form of when the domestic currency is appreciating or depreciating, while intervention is defined as foreign exchange transactions or policies of monetary authorities put in place to affect exchange rates.

Engel and Hakkio(1993)[23] identified the three main sources of exchange rate volatility to be: volatility in market fundamentals; changes in expectations as a result of new information; and speculative "bandwagons".

Market fundamentals are aggregates including money supply, income and interest rate. Their movements influence exchange rate volatility because exchange rate depends on these fundamentals. For instance, if money supply rises, it could lead to an increased speculative activities and market operators tends to purchase foreign currency. A surge in demand for foreign exchange will raise an unstable exchange rate for a while. Any change to the expectations about future market fundamentals or government policies, market operators adjust to their forecast of future economic conditions, and thus lead to a change in exchange rate.

New information like news about a change in monetary policy could affect market participants to adjust their expectation of future money supply growth and interest rates, which invariably change the level of exchange rate and its volatility. The changes in expectations about future fundamentals or economic policies are rampant in African countries. These influence the level of exchange rate and the forecasts of economic aggregates in the economy. Barone-Adesi and Whaley (1987)[8] identified that the degree of confidence in the market operations has an impact on the volatility level of exchange rate. The exchange rate volatility is likely to move in a positive manner with market uncertainty about future economic conditions.

Another cause of exchange rate volatility is speculative bandwagons or speculative exchange rate movements. For instance, the many speculators sufficiently buy dollars with the future expectation of appreciation in dollar irrespective of the fundamentals, the dollar would appreciate, vice versa. 


\subsection{Methodology}

The effect of Central Bank intervention on the exchange rate is empirically presented in this section. This is done by linking an empirical model of exchange rate to the intervention.

\subsubsection{Model Estimation}

The exchange rate is linked with intervention variable in an empirical model with the inclusion of macroeconomic and other variables. Macroeconomic variables such as the values of money supply, trade deficit, consumer price index, producer price index, unemployment rate and interest rates. The model entails the lagged exchange rate in order to control feedback effects from exchange rate to intervention.

Many studies used a linear regression form. Therefore, this study provides its analytical framework as follows:

$E x_{t}=\beta_{0}+\beta_{1}$ Inter $_{i t}+\beta_{2} X_{i t}+\varepsilon_{t}$

Where $E x_{i t}$ represents the exchange rate; Inter $t_{t}$ captures Central Bank intervention; $X_{t}$ is a measure of macroeconomic variables; and $\varepsilon_{t}$ is the random error term. The $\beta^{\prime} s$ are regression coefficients. In addition, Inter $_{t}$ is the monthly dummies that capture Central Bank intervention in the foreign exchange market. The intervention records 1 while it is zero otherwise. $X_{t}$ is used to measure macroeconomic variables such as the value of money supply; trade deficit; consumer price index; and interest rate. i captures the cross section of selected ECOWAS countries ${ }^{3}$

\subsubsection{Estimation Procedures and Data}

Based on the guidelines of modern panel data econometrics, the study first conducts pre-test analysis that entails the descriptive pattern of the variable series as well as the stationarity test in order to correct spurious regression results. The stationarity tests are performed using different approaches such as the Augmented Dickey-Fuller (ADF) and the panel Phillips-Perron (PP) techniques.

\footnotetext{
${ }^{3}$ Nigeria, Ghana, Senegal, and Sierra Leone
} 
The study uses monthly data sourced from publications of International Monetary Fund (IMF), World Bank, Central Bank of Nigeria, Bank of Ghana, and Central Bank of West African States etc. The transformation of data to monthly series is carried out using E-views. All the concerned variables are tested for stationarity using ADF test and PP test; and where non-stationarity results are shown, they are first differenced to ensure stationarity and avoid spurious regression debacle. Both the ADF test and the PP test are carried out for the variables at level. The outcomes of the stationarity tests are reported in the Table A.3.

Fixed effect and random effect models are chosen as an empirical framework for the research work based on the concerns for the model generality. The Hausman test is carried out to determine the appropriate model for the study. In addition, these two models are subjected to diagnostic tests.

\section{Results and Discussion}

As presented in Table A.2, the mean value of consumer price index in Sierra Leone records the highest, followed by Senegal with 86.73 while the lowest value is attributed to Ghana with 60.10 . On the other hand, Ghana experiences the highest monetary policy rate with 24.48 compared to the other selected countries. The mean of exchange rate in Senegal and Sierra Leone between January 1991 and October 2016 was Le 520.34 per US\$, while the mean value of exchange for Ghana and Nigeria in the same sample period was 1.04 cedi per US $\$$ and N104.10 per US\$ respectively (See Table A.2). The maximum value of exchange rate for Ghana, Nigeria, Senegal and Sierra Leone was 4.19 cedi per US\$, N309.73 per US\$, Le768.89 per US\$ and Le 6040 per US\$ respectively.

Table A.3 reports the unit root tests for all the concerned variables in the study. All variables with the exception of trade balance are stationary at the first difference, under the scenario of no intercept and no trend. In addition, monetary policy rate variable is only stationary at level based on the outcome of the LLC test. 
Under the scenario of only the intercept, only monetary policy rate (MPR) and trade balance (TB) variables does not have unit root at level, while consumer price index (CPI), exchange rate $(\mathrm{EXCH})$, intervention (INTER) and broad money supply(M2) are stationary by taking their first difference.

Similar result is recorded in the case of both intercept and trend. However, consumer price index (CPI) is stationary at the level at 10 percent level of significance.

\subsection{Exchange rate and Central Bank Intervention}

Table A.4 provides the results of three panel models estimated. This models are aiming at examining the effects of the intervention and macroeconomic variables on the exchange rate. In the fixed effect model, the value of $\mathrm{R}^{2}$ adjusted indicates that the model constitutes about 99 percent of exchange rate. The effect of consumer price index on the exchange rate is depicted by variable log CPI. It can be noted that Log CPI positively and significantly influences the exchange rate even at 1 percent level of significance. This shows that current inflation (Log CPI) increases the exchange rate. Similarly, intervention (INTER) has a positive and significant impact on the exchange rate at 10 percent level of significance. In addition, other variables such as monetary policy rate (MPR), broad money supply (M2) and trade balance (TB) significantly and directly affect the level of exchange rate even at 1 percent level of significance.

On the other hand, the results of the random effect model reveals that monetary policy rate (MPR) and the broad money supply (M2) have positive and significant effect on the exchange rate in the selected ECOWAS countries. Additionally, about 99 percent variation in the level of exchange rate is jointly explained by all independent variables.

In order to examine the rebound effect, the rebound effect model included one month lagged intervention. The results indicate that all explanatory variables positively influence the exchange rate but only the current intervention and the one month lagged intervention are not significant at 1 percent level of significance. The value of the adjusted R2 suggests that the independent variables account for about 99 percent variation in the level of exchange rate. 
The fixed effect model is more appropriate compared to the random-effect model as reported in Table A.5. Random effect is rejected even at 1 percent level of significance with the probability value of 0.

The rebound impact of the intervention on the current exchange rate is depicted by the lagged intervention variable. This is highly insignificant and positive, and indicates that the absence of the rebound effect.

\section{Conclusion}

This study sets out to examine the effect of the Central Banks' intervention on the exchange rate in selected ECOWAS countries using a panel data modelling framework. Its findings reveal that the effect of the intervention is very little compared with other explanatory variables that influence exchange rate in the region. In addition, the resulting impact of the intervention raises volatility instead of reducing it. Put differently, the intervention elasticity of change in the volatility is very low but positive. The effectiveness of the intervention also relies on the degree of uncertainties in the market, and hence uncertainties are a function of degree of available information.

During the sample period, the results revealed that rises in money supply and monetary policy rates pose the possibility of increasing exchange rate. The unstable and weak intervention policies of monetary authorities during the period could be the factor that makes it difficult for market operators to predict the aim of monetary authorities and its next steps.

All in all, the study finds no rebound exchange rate effect as a result of interventions from the monetary authorities in the selected ECOWAS countries.

Based on the study's findings, the following recommendations are very critical in ensuring exchange rate stability: reduction in the rate of intervention in the exchange rate market and allowing the market mechanisms to operate the market; providing incentives for attracting other suppliers of foreign exchange into the market; a greater focus has to be placed on the indirect causes of exchange rate movements; addressing issues such as diversification of productive base, expansion of export base, redirection of resources to productive sectors, and reduction of food imports are very paramount in ensuring exchange rate stability; and exchange rate policy 
consistence is highly required to achieve stable exchange rate as it empirically proves that changes and reversal of policies add to the uncertainties and speculative activities in the market. Invariably, this leads to a rise in the volatility of exchange rate.

However, there are still rooms for future research in this issue. Future research can extend the scope of this study by including all countries as possible. Second, by employing another estimation techniques with high frequency data such as daily, weekly etc. in order to examine the exchange rate rebound effect.

\section{References}

1. Abel A.B.(1983) .Optimal Investment under Uncertainty. American Economic Review 73(1): 234-48

2. Adam, M., Koziński, W., \& Zieliński, J. (2013). To what extent can central banks influence exchange rates with foreign exchange interventions? The case of Poland. BIS Paper No. 73.

3. Adler Lisack and Mano (2005). Unveiling the Effects of Foreign Exchange Intervention: A Panel Approach. IMF Working Paper WP/15/130

4. Adubi, A.A (2002).Central Bank Intervention and Exchange Rate Stability in Nigeria. Monograph Series No.1 National Centre for Economic Management and Administration (NCEMA), Ibadan, Nigeria

5. Adubi A.A and F. Okunmadewa (1999).Price, Exchange Rate Volatility and Nigeria's Agricultural Trade Flows: A Dynamic Analysis. African Economic Research Consortium (AERC) Research Paper 87, March

6. Ahmed, H.I and A.B. Zarma (1998). The Impact of Parallel Market on the Stability of Exchange Rate: Evidence from Nigeria. NDIC Quarterly 7(2)

7. Bailey, W. (1998).Money Supply Announcement and the Ex-Ante Volatility of Asset Prices. Journal of Money, Credit and Banking: 611-20, November

8. Barone-Adesi, G. and Whaley, R. E. (1987). Efficient Analytic Approximation of American Option Values. The Journal of Finance Vol. 42, No. 2, pp 301-320

9. Becketti, S. and G.H. Sellon Jr (1989) .Has Financial Market Volatility Increased? Federal Reserve Bank of Kansas City Economic Review: 17-30 June

10. Beine, M., Bennasy-Quere A., Dauchy, E., \& Macdonald, R. (2007). The Impact of Central Bank Intervention on Exchange-rate forecast heterogeneity. Journal of the Japanese and International Economies, 21 (1), 38-63.

11. Benita, G., \& Lauterbach, B. (2007). Policy Factors and Exchange Rate Volatility: Panel Data versus a Specific Country Analysis. International Research Journal of Finance and Economics, 7(7), 7-23.

12. Calvo, G.A. and C.M. Reinhart (2000).Fear of Floating. NBER Working Paper No 7993. Cambridge Massachusetts: MI Press

13. CBN/NISER (1998).A Study of Nigeria's Informal Foreign Exchange Market: Implications for Foreign Exchange Management. A Publication of CBN/NISER Informal Sector Study

14. Chaudury and Wei (1994).Upper Bounds for American Futures Options: A Note. Journal of Futures Market 14 February

15. Chen, Y., Funke, M., \& Glanemann. (2011). The Signalling Channel of Central Bank Interventions : Modelling the Yen / US Dollar Exchange Rate. CESIFO Working Paper No. 3610, 1-27.

16. Chipili, J.M. (2014). Central Bank Intervention and Exchange Rate Volatility in Zambia. AERC Research Paper 268 
17. Clarida, R; L. Sarno, M. Taylor, and G.Valente (2001). The Out-off-Sample Success of Term Structure Models as Exchange Rate Predictors: A Step Beyond, Mimeo

18. Claro, S., \& Soto, C. (2011). Exchange rate policy and exchange rate interventions: the Chilean experience. BIS Paper No. 73, 81-93.

19. Disyatat, P., \& Galati, G. (2005). The effectiveness of foreign exchange intervention in emerging market countries. BIS Paper No. 24, 97-113.

20. Dominguez, K. M. E. (2006). When do central bank interventions influence intra-daily and longerterm exchange rate movements? Journal of International Money and Finance, 25(7), 1051-1071. http://doi.org/10.1016/j.jimonfin.2006.08.009.

21. Dutta, J. and H.Leon (2002).Dread of Depreciation: Measuring Real Exchange Rate Interventions. IMF Working Paper WP/02/63, April

22. Edison, H.J. (1993). The Effectiveness of Central Bank Interventions: A survey of Literature after 1982. Special Papers in International Economics No. 18. Princeton University, International Finance Section

23. Engel, C. and Hakkio, C.S. (1993). Exchange Rate Regimes and Volatility. Economic Review, Federal Reserve Bank of Kansas City, Issue Q III, pg. 43-58

24. Faruque, R. (1994).Nigeria Ownership Abandoness. In: Hussain, I. and R. Farugue(eds) Adjustment in Africa: Issue from Country Case Study. Washington, DC: World Bank

25. Mbarek, H. Ben. (2011). The Effect of Central Bank Intervention on the Exchange Rate of the Tunisian Dinar in Relation to the European Currency. Journal of Business Studies Quarterly, 2(3), 64-74.

26. Galati, G. and Melick, W. (2002).Central Bank Intervention and Market Expectations. BIS Papers No 10. Monetary and Economic Department, Bank for International Settlements, April.

27. Galati, G., Melick, W., \& Micu, M. (2002). Foreign exchange market intervention and expectations : an empirical study of the yen/dollar exchange rate. Mimeo, BIS, pp 1-59.

28. Hoshikawa, T. (2017). Exchange Rate Rebounds after Foreign Exchange Market Interventions. Physica A 469, 102-110

29. Hooper, P. \& S.W. Kohlagen (1978). The Effects of Exchange Rate Risk and Uncertainty on the Prices and Volume of International Trade. Journal of international Economics 8(197): 483-511

30. Hung, J. (1997) .Intervention Strategies and Exchange Rate Volatility: A Noise Trading Perspective. Journal of International Money and Finance 16: 779-93

31. Kireyev, A. and Mansoor, A. (2015).Making Senegal a Hub for West Africa. African Development Paper, IMF

32. Komolafe, O. Stella (1996) .Exchange Rate Policy and Nigeria's External Sector Performance. Nigerian Journal of Economic and Social Study 30(1, 2, \&3).

33. Korsu, R.D. \& Braima, S.J. (2009). The Determinants of the Real Exchange Rate in Sierra Leone, Department of Economics, Fourah Bay College, University of Sierra Leone

34. Lastrapes, W. and F. Koray(1990).Exchange Rate Volatility and U.S. Multilateral Trade Flows. Journal of Macroeconomics 12(3): 134-48

35. Le Baron, B. (1999). Technical Trading Rule Profitability and Foreign Exchange Intervention. Journal of International Economics 49: 125-43

36. Maehle, N., Teferra, H. and Khachatryan, A. (2013).Exchange Rate Liberalization in Selected SubSaharan African Countries: Successes, Failures, and Lessons. IMF Working Paper

37. Mbarek, H.B., Rachidi, H. \& Mensi, S. (2011). The Effect of Central Bank Intervention on the Exchange Rate of the Tunisian Dinar in Relation to the European Currency. Journal of Business Studies Quarterly Vol. 2, No. 3, pp. 64-74

38. Miyajima, K., \& Montoro, C. (2013). Impact of foreign exchange interventions on exchange rate expectations. BIS Paper No. 73d, 39-54.

39. Mongkol, K. (2011). Is intervention effective after all ? Journal of Economics and International Finance, 3(1), 29-36. http://www.academicjournals.org/JEIF.

40. Mussa, M. (1981).The Role of Official Intervention.Group of Thirty New York

41. Neely, C.J. (2000) .The Practice of Central Bank Intervention: Looking under the Hood. Central Banking XI (2): 24-37, November 
42. Neely, C.J. and P.Weller. (2001).Technical Analysis and Central Bank Intervention. Journal of International Money and Finance 20:949-70

43. Obadan I. Mike (1993). Overview of Nigeria's Exchange Rate Policy and Management since the Structural Adjustment Programme. CBN Economic and Financial Review 31(4)

44. Ogiogio, G.O. (1996). A Statistical Analysis of Foreign Exchange Rate Behaviour in Nigeria's Auction. AERC Research Paper 49, March.

45. Olisadebe, E.U. (1995).The Role of the Central Bank of Nigeria: Current Issue in Nigeria’s Exchange Rate Policy. CBN Economic and Financial Review 33(4):319

46. Reitz, S. (2002).Central Bank Intervention and Exchange Rate Expectations-Evidence from Daily DM/US-Dollar Exchange Rate. Discussion Paper 17/02. Economic Research Centre of the Deutsche Bundesbank, June.

47. Saacke, P. (2002). Technical analysis and the effectiveness of central bank intervention. Journal of International Money and Finance, 21, 459-479.

48. Sarno, L. and Taylor, M.P. (2000).Official Intervention in the Foreign Exchange Market. Banking of Financial Studies E: 17

49. Sarno, L and Taylor, M.P (2001). Official intervention in the foreign exchange market: is it effective and, if so, how does it work? Journal of Economic Literature 39,839-863

50. Spolander, M. (1999).Measuring Exchange Market Pressure and Central Banking Intervention. Banking of Finland Studies E: 17

51. Su, C. (2012). The relationship between exchange rate and macroeconomic variables in China. Proceedings of Rijeka Faculty of Economics, Journal of Economics and Business, 30(1), 33-56.

52. Takagi, S. (2014). The effectiveness of Foreign Exchange Market Intervention: A Review of Post-2001 Studies on Japan. Journal of Reviews on Global Economics, 3, 84-100

53. Vadivel, A. (2014). The RBI Coordination of Exchange Rate Intervention and Foreign Exchange Market. Journal of Game Theory, 3(1), 7-10. http:/ / doi.org/10.5923/j.jgt.20140301.02

54. Wickham P. (2002). Do Flexible Exchange Rates of Developing Countries Behave Like the Floating Exchange Rate of Industrialized Countries? IMF Working Paper WP/02/63, April. 


\section{Appendix}

Table A.1: Abridged Descriptive Statistics

\begin{tabular}{lcccccc}
\hline Statistics & TB & MPR & M2 & INTER & EXCH & CPI \\
\hline Mean & 162.13 & 15.45 & 3010023 & -6.39 & 781.677 & 76.18 \\
Median & -22.589 & 13.50 & 1230654 & 0.73 & 231.67 & 79.45 \\
Maximum & 6780.14 & 46.99 & 22275513 & 4751.44 & 6104.00 & 279.15 \\
Minimum & -4973.74 & 2.49 & 734.42 & -26298 & 0.03 & 2.50 \\
Std. Dev. & 1194.62 & 10.08 & 4897670 & 852.88 & 1266.76 & 49.83 \\
Skewness & 1.55 & 1.18 & 2.24 & -23.68 & 2.10 & 0.66 \\
Kurtosis & 13.75 & 4.26 & 7.13 & 731.77 & 6.56 & 3.79 \\
Jarque-Bera & 6488.74 & 262.31 & 1311.65 & 27556702 & 1562.52 & 103.85 \\
Probability & 0.00 & 0.00 & 0.00 & 0.00 & 0.00 & 0.00 \\
Sum & 201694.50 & 13535.50 & $2.55 \mathrm{E}+09$ & -7925.05 & 967716.00 & 80598.13 \\
Observations & 1244 & 876 & 848 & 1240 & 1238 & 1058 \\
\hline
\end{tabular}

Table A.2: Summary Statistics for the Countries.

\begin{tabular}{|c|c|c|c|c|c|c|c|c|c|c|c|}
\hline Ghana & CPI & MPR & $\mathrm{EXCH}$ & TB & INTER & Senegal & CPI & MPR & $\mathrm{EXCH}$ & $\mathrm{TB}$ & INTER \\
\hline Mean & 60.10 & 24.48 & 1.04 & -111.43 & -2.42 & & 86.73 & 4.31 & 520.04 & -144.94 & -0.04 \\
\hline Minimum & 2.53 & 12.21 & 0.03 & -436.32 & -4237.90 & & 50.78 & 3.20 & 246.20 & -429.58 & -144.09 \\
\hline Maximum & 216.01 & 46.99 & 4.19 & 278.01 & 477.32 & & 108.52 & 6.25 & 768.89 & 0.00 & 83.30 \\
\hline Obs. & 311 & 311 & 311 & 312 & 311 & & 311 & 187 & 311 & 312 & 311 \\
\hline Nigeria & & & & & & Serria Leone & & & & & \\
\hline Mean & 63.33 & 13.60 & 104.10 & 920.94 & -23.09 & & 120.70 & 13.30 & 520.54 & -16.03 & -0.02 \\
\hline Minimum & 2.50 & 5.23 & 8.87 & -4973.74 & -26297.97 & & 58.82 & 2.49 & 196.08 & -312.95 & -585.54 \\
\hline Maximum & 192.52 & 26.95 & 309.73 & 6780.14 & 4751.44 & & 279.15 & 21.66 & 6104.00 & 106.51 & 75.31 \\
\hline Obs. & 311 & 311 & 312 & 312 & 311 & & 129 & 71 & 308 & 312 & 311 \\
\hline
\end{tabular}

Table A.3: Panel Unit Root Tests

Table A.3.1: No intercept \& No trend

\begin{tabular}{|c|c|c|c|c|c|c|c|c|c|c|}
\hline \multirow[t]{2}{*}{ Statistics } & \multicolumn{2}{|c|}{ CPI } & \multicolumn{2}{|c|}{ EXCH } & \multirow{2}{*}{$\begin{array}{c}\text { INTER } \\
\text { Level }\end{array}$} & \multicolumn{2}{|r|}{ M2 } & \multicolumn{2}{|c|}{ MPR } & \multirow{2}{*}{$\begin{array}{l}\text { TB } \\
\text { Level }\end{array}$} \\
\hline & Level & First Diff & Level & $\begin{array}{l}\text { First } \\
\text { Diff }\end{array}$ & & Level & $\begin{array}{l}\text { First } \\
\text { Diff }\end{array}$ & Level & $\begin{array}{l}\text { First } \\
\text { Diff }\end{array}$ & \\
\hline \multicolumn{11}{|c|}{ Null: Unit root (assumes common unit root process) } \\
\hline $\begin{array}{l}\text { Levin, Lin \& } \\
\text { Chu t* }\end{array}$ & 6.17 & $-4.40 * * *$ & 4.79 & $-12.49 * * *$ & $-11.53 * * *$ & 9.03 & $-6.76 * * *$ & $-1.96 * *$ & $-7.86 * * *$ & $-3.34 * * *$ \\
\hline \multicolumn{11}{|c|}{ Null: Unit root (assumes individual unit root process) } \\
\hline $\begin{array}{l}\text { Im, Pesaran } \\
\text { and Shin W-stat }\end{array}$ & 7.37 & & & & & & & & & \\
\hline $\begin{array}{l}\text { ADF - Fisher } \\
\text { Chi-square }\end{array}$ & 0.02 & $62.16 * * *$ & 0.52 & $174.61 * * *$ & $153.70 * * *$ & 0.00 & $58.61 * * *$ & 11.98 & $77.20 * * *$ & $29.56 * * *$ \\
\hline $\begin{array}{l}\text { PP - Fisher } \\
\text { Chi-square }\end{array}$ & 0.01 & $450.12 * * *$ & 0.51 & $506.92 * * *$ & $592.14 * * *$ & 0.00 & $641.75^{* * *}$ & 9.26 & $380.04 * * *$ & $63.87 * * *$ \\
\hline
\end{tabular}

Note: ${ }^{* *},{ }^{* *}$, and $*$ represents $1 \%, 5 \%$ and $10 \%$ significant level respectively 
Table A.3.2: Individual Effects

\begin{tabular}{|c|c|c|c|c|c|c|c|c|c|c|}
\hline \multirow[t]{2}{*}{ Statistics } & \multicolumn{2}{|r|}{ CPI } & \multicolumn{2}{|c|}{ EXCH } & \multirow{2}{*}{$\begin{array}{c}\text { INTER } \\
\text { Level }\end{array}$} & \multicolumn{2}{|c|}{ M2 } & \multicolumn{2}{|c|}{ MPR } & \multirow{2}{*}{$\begin{array}{c}\text { TB } \\
\text { Level }\end{array}$} \\
\hline & Level & First Diff & Level & $\begin{array}{l}\text { First } \\
\text { Diff }\end{array}$ & & Level & $\begin{array}{l}\text { First } \\
\text { Diff }\end{array}$ & Level & First Diff & \\
\hline \multicolumn{11}{|c|}{ Null: Unit root (assumes common unit root process) } \\
\hline $\begin{array}{l}\text { Levin, Lin \& } \\
\text { Chu t* }\end{array}$ & 8.92 & $-4.55 * * *$ & 4.46 & $-13.56 * * *$ & $-8.97 * * *$ & 8.48 & $-5.0156 * * *$ & $-1.80 * *$ & $-4.23 * * *$ & -0.59 \\
\hline \multicolumn{11}{|c|}{ Null: Unit root (assumes individual unit root process) } \\
\hline $\begin{array}{l}\text { Im, Pesaran } \\
\text { and Shin W- } \\
\text { stat }\end{array}$ & 9.30 & $-6.45 * * *$ & 4.67 & $-12.77 * * *$ & $-10.30 * * *$ & 10.10 & $-7.47 * * *$ & $-1.69 * *$ & $-5.78 * * *$ & $-2.64 * * *$ \\
\hline $\begin{array}{l}\text { ADF - Fisher } \\
\text { Chi-square }\end{array}$ & 1.66 & $63.84 * * *$ & 3.37 & $168.33 * * *$ & $125.68 * * *$ & 0.002 & $75.29 * * *$ & $15.27^{*}$ & $54.96 * * *$ & $22.85 * * *$ \\
\hline $\begin{array}{l}\text { PP - Fisher } \\
\text { Chi-square }\end{array}$ & 1.62 & $300.37 * * *$ & 3.96 & $455.84 * * *$ & $531.27 * * *$ & 0.0005 & $438.53 * * *$ & 7.77 & $319.70 * * *$ & $66.07 * * *$ \\
\hline
\end{tabular}

Note: ${ }^{* * *},{ }^{* *}$, and $*$ represents $1 \%, 5 \%$ and $10 \%$ significant level respectively

Table A.3.3: Individual Effects, Individual Linear Effects

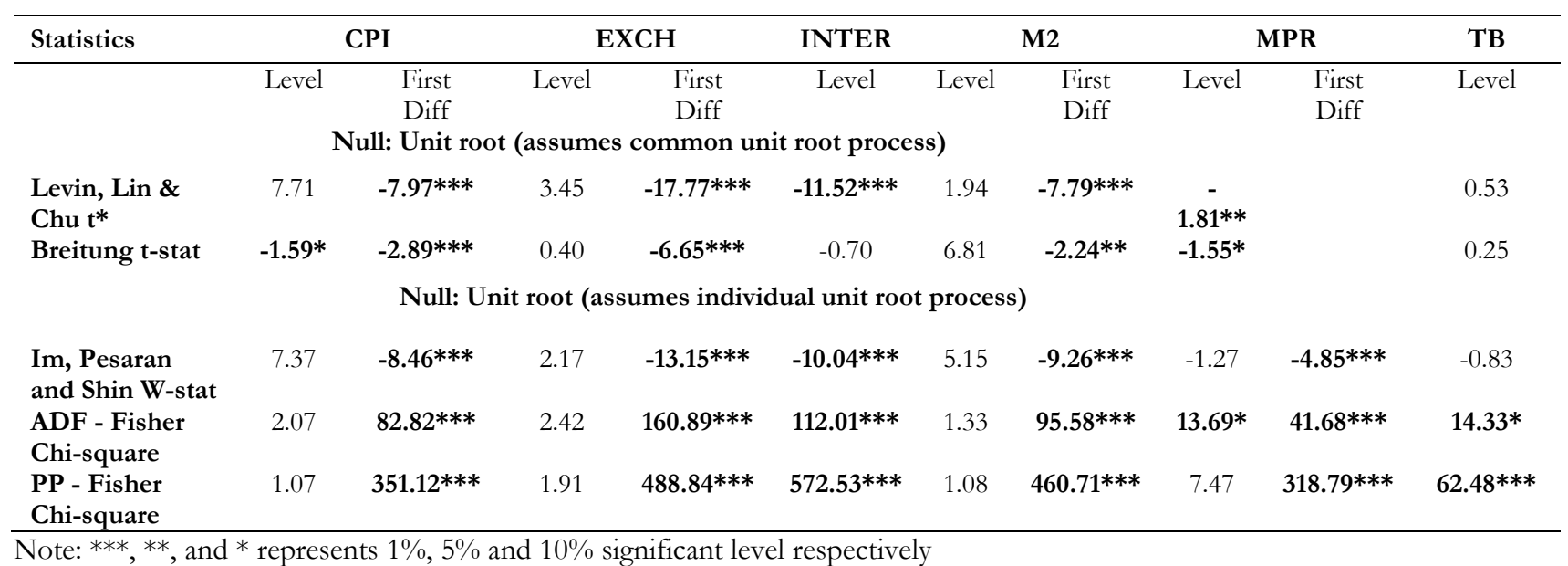

\section{Table A.4: Panel Estimation}

\begin{tabular}{lccc}
\hline Statistics & Fixed Effect & Random Effect & Rebound Effect \\
\hline Dependent Variable: LOG $(\mathrm{EXCH})$ & & \\
Constant & $-4.1997^{* * *}$ & $-0.7733^{* * *}$ & $-4.2161^{* * *}$ \\
LOG(CPI) & $0.1738^{* * *}$ & - & $0.1707^{* * *}$ \\
INTER & $7.49 \mathrm{E}-06^{*}$ & $4.06 \mathrm{E}-06$ & $7.39 \mathrm{E}-06^{*}$ \\
INTER(-1) & - & - & $2.32 \mathrm{E}-06$ \\
LOG(M2) & $0.5254^{* * *}$ & $0.3203^{* * *}$ & $0.5278^{* * *}$ \\
LOG(MPR) & $0.3021^{* * *}$ & $0.3288^{* * *}$ & $0.3013^{* * *}$ \\
TB & $2.64 \mathrm{E}-05^{* * *}$ & - & $2.60 \mathrm{E}-05^{* * *}$ \\
Adjusted R2 & 0.9985 & 0.9967 & 0.9984 \\
\hline
\end{tabular}




\begin{tabular}{|c|c|c|c|}
\hline F-Statistic & $1865.86^{* * *}$ & $30604.15^{* * *}$ & $1853.438^{* * *}$ \\
\hline
\end{tabular}

Table A.5: Hausman Test

\begin{tabular}{lccc}
\hline Cross-section random & Chi-Sq. Statistic & Chi-Sq. d.f. & Prob. \\
\hline LOG $(\mathrm{EXCH})$ & 35946.65 & 3 & 0.00 \\
\hline
\end{tabular}

Figure A.1: Historical Trend of Exchange rate, Intervention and Money Supply
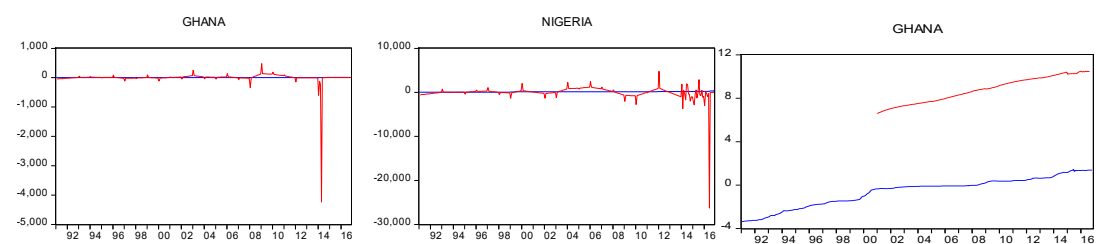

SERRIALEONE
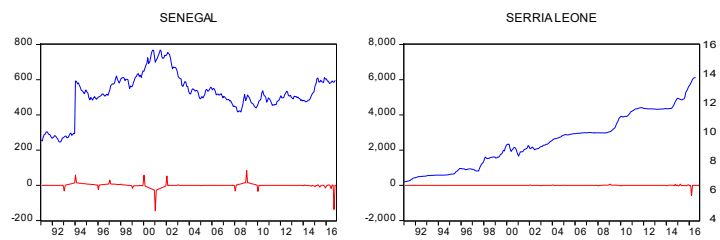

- ${ }^{\mathrm{XXH}}$ INTER $^{\mathrm{INE}}$

Figure A.1.1: Historical Trends of Exchange rate and Intervention

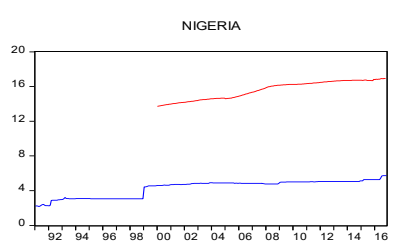

SERRIALEONE

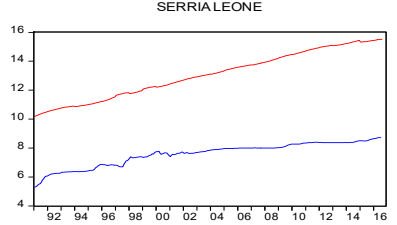

- LOGEXCH - LOGM2

Figure A.1.2: Historical Trends of Exchange rate and Money Supply

(C) 2017 by the authors; licensee Preprints, Basel, Switzerland. This article is an open access article distributed under the terms and conditions of the Creative Commons by Attribution (CC-BY) license (http://creativecommons.org/licenses/by/4.0/). 